\title{
Appraisal of corporate governance in a lower middle income country: The case of Ghana
}

\author{
Seth Oppong ${ }^{\mathrm{a}, \mathrm{b}^{*}}$, Rajesh Arora ${ }^{\mathrm{c}}$, Paul R. Sachs ${ }^{\mathrm{d}}$ and Mamuda T. Seidu ${ }^{\mathrm{e}}$
}

${ }^{a}$ PhD Candidate, University of Ghana, Legon, Ghana

${ }^{b}$ Lecturer at African University College of Communications

${ }^{c}$ President and CEO, TQMS, Mumbai, India

${ }^{d}$ Exexutive Director, NHS Human Services - Philadelphia, Philadelphia, PA, USA

${ }^{e}$ Director, African Institute of Management Science, Accra, Ghana

\section{H R O N I C L E A B S T R A C T}

Article history:

Received December 17, 2015

Received in revised format

December 18, 2015

Accepted December 212015

Available online

December 232015

Keywords:

Corporate governance

Accountability

Ghana

Board of directors

Board size

Board composition

\section{Introduction}

According to the World Bank (2012), countries can be classified into clusters based on per capita income. These clusters include (1) the low income countries (LIC) which is characterized by less than $\$ 1,005$ per capita GNI in 2010, (2) the lower middle income countries (LMIC) characterized by per capita incomes between $\$ 1,006$ and $\$ 3,975$, (3) the upper middle income countries (UMIC) characterized by incomes between $\$ 3,976$ and $\$ 12,275$ and (4) the high income countries (HIC), with more than $\$ 12,276$ per capita income.

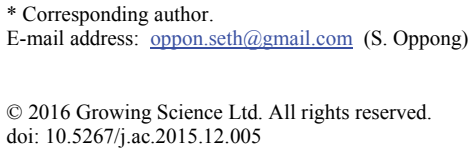


Per capita income, however, is of limited use in classifying the economic status of countries because it does not consider the socio-political factors that accompany a given level of per capita income. Vázquez and Sumner (2012) offered an alternative classification of developing countries comprising five clusters. These include (1) Cluster 1: High poverty rate countries with largely traditional economies, (2) Cluster 2: Natural resource dependent countries with little political freedom, (3) Cluster 3: External flow dependent countries with high inequality, (4) Cluster 4: Economically egalitarian emerging economies with serious challenges of environmental sustainability and limited political freedoms, and (5) Cluster 5: Unequal emerging economies with low dependence on external finance.

Ghana has been classified as a lower middle income (Organization for Economic Cooperation and Development, 2012). However, Vázquez and Sumner (2012) classified Ghana as a Cluster 3 country. According to Vázquez and Sumner (2012, p.24), Cluster 3 comprises countries

“...with high dependency on external flows and high inequality, and moderate poverty incidence (relative to the average for all developing countries). These countries rank third in terms of poverty, malnutrition, non-agricultural GDP, productivity, innovation capacities, and $\mathrm{CO} 2$ per capita emissions. However, they are the economies with the second highest Gini index (after $\mathrm{C} 5$ ), the lowest ratio of primary exports, the second highest external finance, the second best score in the governance indicators (although still below the world average) and the second best democracy indicator."

Similarly, the United Nations (2007, p.3) reports that middle income countries account for "slightly more than $21 \%$ of world trade (exports and imports) of goods and services, and receive around $24 \%$ of foreign direct investment (FDI), 43\% of geographically allocated bilateral ODA, and $57.8 \%$ of emigrant remittances (all figures for 2003)". That middle income countries are recipients of higher levels of FDIs requires that investors be assured that their investments will be protected through accountable stewardship. Accountable stewardship improves investor confidence in middle income countries thereby enabling these countries to continue to attract high volumes of FDIs in order to further their economic development.

Accountability or the state of being answerable is essential for building trust for supporting economic activities and therefore the entire economy. Indeed, this trust is required as one of the preconditions for both direct and portfolio investments. Which prospective investor will inject capital into a venture where managers are known to be less answerable to the shareholders? Thus, this accountability-inspired trust is one of the keys to raising investor confidence within a given economy. It is against this background that when public officials are elected or appointed, they are expected to use public funds judiciously to serve the objectives of the governed. For instance, Auditor-General's Department in Ghana has been set up to check the activities of the public officials. This is public governance.

Corporate governance is a set of mechanisms that helps to hold the management in check in order to inject accountability in the management of the corporation. Solomon and Solomon (2010, p.14) describe corporate governance as "the system of checks and balances, both internal and external to companies, which ensures that companies discharge their accountability to all their stakeholders and act in a socially responsible way in areas of their business activity." Thus, when shareholders select senior managers through their boards of directors, they expect the senior executives to utilize the organizational resources to maximize their gain on their investment. Put another way, when someone (the agent) is tasked to carry out a function on behalf of another person (the principal) for a fee, the former is expected to be answerable to the latter if that relationship is to be maintained. This is crux of agency theory of corporate governance. Among other things corporate governance ensures accountability, transparency, and efficient use of corporate resources (Oppong, 2011). More importantly, studies indicate that sound corporate governance improves corporate performance, whether accounting-based or market-based measures are used (Brick et al., 2002; Dwivedi \& Jain, 
2005). The role of corporate governance in ensuring high corporate performance has been succinctly captured by Solomon and Solomon (2010, p.14) as follows:

"Indeed, our own empirical research has provided substantial support for the view that corporate financial performance is positively related to corporate governance...Indeed, we have found from our research that one reason 'good' corporate governance, as well as corporate social responsibility, are linked significantly to good corporate financial performance is its link with management quality. Better managers instigate better corporate governance and pay attention to their stakeholders. Better managers also manage companies more effectively and produce higher financial returns."

Against the background of the recent corporate malfeasance at Enron in 2001, Ghana is expected to take pre-emptive actions to avoid similar occurrences in corporate Ghana. As a result of this, publicly listed companies (PLCs) are expected to observe sound corporate governance as enjoined by the Ghana Stock Exchange (GSE) regulation on listing, Securities and Exchange Commission's (SEC) guidelines, and provisions in the Companies Code 1963. Owing to this, SEC developed its code on corporate governance in 2002. Further, SEC recognizes the importance of good or sound corporate governance in ensuring the cultivation, nourishment, and safeguarding of entrepreneurship in a given economy. For instance, it reports that (SEC, 2002, p.3):

"Corporate governance is only part of the larger economic context in which companies operate. It is recognised though as a key element in improving economic efficiency and is considered a powerful micro-policy instrument and effective lever for change in transitional economies. It is, however, no substitute for entrepreneurial ability. It only offers a framework of accountability and checks and balances. Further good corporate governance cannot prevent illconceived strategies, product failures or missed opportunities. It can, however, contain the harm arising from such corporate shortcomings and enable the tackling of issues such as defective leadership, persistent poor business performance and a general erosion of trust or confidence in or around businesses. In the circumstances it could be said to contribute to the preservation, sustenance and nurturing of the fruits of entrepreneurial activity."

The predominant thinking in corporate governance is that CEOs and senior executives of organizations pursue their self-interests that contradict the goals of the shareholders (Agency theory) and other stakeholders (Stakeholder theory) or that CEO and senior executives of organizations do not pursue their self-interests and conflicting goals per se but are often not just motivated to pursue the goals of the shareholders (Stewardship theory) (Benz \& Frey, 2007; Solomon \& Solomon, 2010; Oppong, 2011). As a result, board of directors (BODs) are appointed or elected to align the goals of executive managers with those of the shareholders or to ensure that executive managers become motivated enough to work towards accomplishing the goals of the shareholders. This role of the BODs makes them an essential element in the corporate governance process. They can be thought of as being the representatives of the shareholders or the go-between of the two stakeholders (executive management and shareholders). Despite this, there is still possibility that the board members may collude with the management of the corporate bodies to serve their own interest.

Though other studies have been conducted on corporate governance in Ghana, they have largely focused on either the compliance with the existing laws or historical evolution of corporate governance in Ghana. For instance, Agyemang and colleagues have provided analyses of the degree of compliance with the existing corporate governance regulations in Ghana (Agyemang et al., 2013; Agyemang \& Castellini, 2013).The World Bank (2005) also assessed Ghana's corporate governance structures relative to internationally accepted benchmark. On the other hand, Adegbite (2012) provided an exposition on the historical evolution of corporate governance in Ghana. Little research has been done to explore existing corporate governance structures in relation to empirical evidence. The purpose of this paper is to benchmark corporate governance policy in Ghana's private sector (and by extension, 
the current practices) relative to the best practices derived from theory and research on corporate governance.

\section{Corporate Governance Guidelines of Ghana}

Ghana's Securities and Exchange Commission (SEC), previously known as Securities Regulatory Commission, was established by Securities Industry Law 1993 (PNDCL 333) and later amended into an Act of Parliament by Securities Amendment Act 2000 (Act 590). The principal objective of SEC is to protect investors and maintain the integrity of the securities market in Ghana. In this direction, SEC developed the code on best practices on corporate governance in line with the codes and principles by Organization for Economic Co-operation and Development (OECD), Commonwealth Association of Corporate Governance, Companies Code 1963, and regulations for listing on Ghana Stock Exchange (SEC, 2002). The corporate governance guidelines of Ghana developed by SEC are based on the following principles (SEC, 2002, p.4):

1. The rights of shareholders

2. The equitable treatment of shareholders

3. The role of stakeholders

4. Disclosure and transparency

5. The responsibilities of the board

In this paper, policy is used to refer to the code of best practices on corporate governance issued by Ghana's SEC. As such, policy is an embodiment of the various regulations on corporate governance in Ghana though it does not have the force of law. Best practices refers to the empirical evidence from theory and research. This analysis shall focus largely on the nature of the board of directors and limits itself the laws, codes, and practices in the private sector of Ghana. This paper examines characteristics of the board such as the responsibilities, optimal board size, degree of independence, board composition, and audit and compensation committees. It is also important to note that corporate governance in Ghana's public services is regulated by the Corporate Governance Manual for Governing Boards/Councils of the Ghana Public Services has been compiled by the Public Services Commission of Ghana.

\section{Responsibilities of the Board}

What duties are required of BOD? SEC code provides that BOD identifies and manages risk, carries out succession planning, oversees management and conduct of business, guides the company to meet its objectives, oversees internal control systems, and maintains the company's communications and information dissemination policy (SEC, 2002). It also states that non-executive members should provide independent viewpoints and assistance to the executive members of the board. The implication of this is that BOD's performance can be assessed in terms of these duties.

On the other hand, theory and research suggest that, in addition to ensuring the economic health of the company, BOD should also engage in environmental scanning, advise top management on strategic issues, monitor managers, provide feedback and guidance to the $\mathrm{CEO}$, participate in succession planning, facilitate the acquisition of resources critical to the success of the company, and act as external source of knowledge (Benz \& Frey, 2007; Brick et al., 2002; Dwivedi \& Jain, 2005; Garg, 2007; Murphy \& McIntyre, 2007).

By placing the SEC's code and prescriptions from theory and research side by side, current policy on corporate governance in Ghana leaves out some important functions of BOD out. For instance, facilitating the acquisition of critical resources, provision of feedback and guidance to CEOs, and environmental scanning are not covered in the code. 


\section{Optimal Board Size}

What should the optimal size of BOD be? The SEC (2002) code suggests a BOD membership of 8 to 16 as ideal. This means that 8 is the minimum while 16 is the maximum. However, empirical studies linking BOD size to firm performance have reported a strong inverse relationship between the two, though others have found a non-linear relationship (Dalton et al., 1999; Garg, 2007; Murphy \& McIntyre, 2007). The relationship approximates an invested U-curve. The implication of this evidence is that firm performance increases as the BOD size also increases till an optimal size is reached beyond which further increase in the size leads to decreased firm performance. The reason is that if the BOD is too large a phenomenon known as social loafing sets in as a result of diffusion of responsibility while when too small the BOD will have limited perspectives due to small pool of skills and experiences. Both extremes make BOD ineffective; with large BODs, the CEO becomes more powerful and with small BODs the quality of decisions becomes sub-optimal (Dalton et al., 1999).

Garg (2007) and Lorsch (1992, cited in Garg, 2007) suggest that that the optimal BOD size is between 6 and 8, balancing diversity of board skills and viewpoints with efficiency. BOD size of 8 is recommended here as optimal implying that BOD of size 9 or more will be inefficient. This conclusion is drawn because Lorsch (1992; cited in Garg, 2007) suggested a board size of 8 whiles Garg's (2007) empirical study limited the size to 6 . The implication is that a board comprising between 6 and 8 persons is more likely to be more effective than boards comprising less than 6 members and those comprising more than 8 members.

\section{Degree of Independence of Boards}

What is the optimal degree of independence of BOD? BOD independence can be defined along the following lines: proportion of outside independent members on the board, the CEO/chairperson split, and degree of director equity ownership. Regarding the non-executive, SEC code states that BOD should consist of at least one-third (33\%) independent non-executive members (SEC, 2002). It also recommends a split between the roles of CEO and chairperson of BOD, though it does not discourage completely the combination of the two roles. SEC (2002) classifies a director as independent, when the person meets any or all the following conditions:

- Is not a substantial shareholder of the corporate body

- Has not been employed by the corporate body in an executive capacity for the previous there years

- Is not a professional adviser or consultant to the corporate body

- Is not a significant supplier or customer

- Has no significant contractual relationship with the corporate body; and

- Is free from any other relationship with the corporate body, which may interfere with his or her capacity to act in an independent manner.

However, Garg (2007) and Murphy and McIntyre (2007) suggest positive relationships between proportion of independent BOD members and firm performance on one hand and between CEO/Chairperson split and firm performance on the other (Garg, 2007, Murphy\& McIntyre, 2007). The value of this finding is that a board which is truly independent of the executive management is more efficient because such a board is able to perform its oversight function without fear of intimidation from the CEO and executive management (Oppong, 2011). In addition, a negative relation has been found between degree of BOD equity ownership and firm performance. This evidence supports the claim that board members should be independent or should not own equity in the corporate bodies on whose boards they serve.

Further empirical evidence suggests that BODs with $50 \%$ to $60 \%$ independence are more effective than those with less than $50 \%$ or more than $60 \%$ percent independence (Garg, 2007). Drawing on theory and research on public governance, it has also been suggested that BODs be directly elected by 
shareholders to enhance their independence and to get them to understand that they are accountable to the shareholders but not the $\mathrm{CEO}$ and the executive managers. This conclusion stems from the fact that the SEC code recommends board independence ranging from $33 \%$ to somewhere less than $100 \%$ independence (given that SEC recommends a mixed board) while the empirical evidence suggest between $50 \%$ and $60 \%$ board independence. Against these findings, it can be said that the code's guidelines on independence of BOD is not adequate.

\section{Board Composition}

Ghana's SEC's code does not say anything about that other than the prescription that BOD should be made up of both executive and non-executive directors (SEC, 2002). However, research and theory on impact of top management team's characteristics on firm performance suggest that heterogeneous teams are more effective in the long-run while homogeneous ones are effective in the short-run (Dalton et al 1999; Garg, 2007).

Heterogeneity has been examined along the lines of age, gender, educational background, functional background, and tenure. Besides, average standing of teams on these characteristics has also been found to relate to firm performance. Younger, short-tenured management teams with higher education have been found to be more effective (Murphy\& McIntyre, 2007). The implication for BOD composition is that boards should be heterogeneous. Regarding the tenure, the SEC's code states that directors should submit themselves for re-election at regular interval at least every three (3) years.

As indicated earlier, longer-tenured BODs are ineffective because they consistently pursue the same strategies even after those strategies are no longer effective; there is escalation of commitment to failing strategies. In other words, longer-tenured BODs become obsolete. As a result of this, it is recommended here that the BOD serve a maximum of two terms where each term is three years. However, it is not expected to be automatic that each director will serve two terms consecutively. This is to say that some form of performance assessment should be done to determine whether or not a particular director should be allowed a second term.

In this regard, shareholders can work with the management to identify objective criteria upon which each board member ought to be assessed. The assessment could be done by a consultant appointed by the shareholders on their behalf based on the agreed criteria. The criteria could include board meeting attendance, quality of contributions during meetings, and a host of others. Experienced industrial psychologists and/or human resource practitioners would be able to provide such objective assessment of board member performance. However, one needs to be aware of the possible collusion between the board, management, and the consultants if shareholders do not have total control in the screening and appointment of the latter. This will also imply that single assessor ought not to be used all the time.

\section{Audit and Compensation Committees}

The code provides that the committee should comprise at least three (3) members with independent BODs (SEC, 2002). They should also have knowledge of finance or accounting with an independent director as its chairperson. It also states that the CEO, financial director, chief internal auditor, and representative of the external auditing firm should be members-in-attendance.

Theory and research on public governance suggest that the audit committee has to be independent to be effective and must be elected directly by the shareholders (Benz \& Frey, 2007). Again, it is suggested that the external auditing firm be chosen from several others by the shareholders themselves. The importance of these elections is communicate to the audit committee members and the external auditing firm that they are directly accountable to the shareholders and not to the CEO and the BODs. The "kokromoti" (thumb) power will make the committee and the auditing firm cautious in carrying out their functions. This is to say that shareholders ought to directly appoint and/or elect the auditing firm 
in order that the firm's independence can be guaranteed. Similar suggestion has been made with regards to the composition of the compensation committees.

\section{Conclusions}

In the light of the above evidence, the following recommendations are made to improve corporate governance in Ghana:

- The duties of BODs should be expanded to include facilitating the acquisition of critical resources, provision of feedback and guidance to CEOs, and environmental scanning.

- The optimal BOD size is 8 , though a board size of $7 \pm 1$ should be considered acceptable range of deviation.

- Between 50\% and 60\% board independence is recommended. In this regard, boards with 5 independent directors are ideal for optimal functioning if the optimal size is estimated to be 8 or 3 if the board comprises 6 members. The implication is that for a board consisting of $7 \pm 1$ members, the number of independent directors should range between 3 and 5 .

- Boards should be heterogeneous.

- Board of directors should serve a maximum of two terms totaling 6 years in all.

- External auditing firms should be directly selected by shareholders.

- Independence of audit and compensation committees should be enhanced by direct selection by shareholders.

Management and the appropriate bodies may consider the election process of auditing firms by the stakeholders too costly for the organization. Interestingly, Ghana spends millions of cedis to organize democratic elections to select competent public officials with the understanding that the cost of not holding the elections outweighs the cost of holding the elections. Similarly, organizations spend millions of cedis to hunt for and select competent CEOs knowing that the financial cost associated with hiring a competent CEO is less than the cost of hiring incompetent CEOs (Oppong, 2011). In this regard, the financial cost of shareholders' election process is equally expected to be less than the financial cost of composing committees with members and contracting an auditing firm serving the interests of the CEO and the rest of the board instead of those of the shareholders.

It should be noted that this paper did not deal with the mechanisms relating to financial reporting procedure and shareholder activities. This analysis should not be interpreted as reflecting the policy as grossly inadequate rather as pinpointing some of the weaknesses inherent in the policy framework. For the purposes of emphasis, the 17 points that have been recommended by Solomon and Solomon (2010) as a recipe for a 'good board' are repeated here. They shall be referred to, in this paper, as 'the 17 principles of good board dynamics'. According to Solomon and Solomon (2010, p.66), the 17 principles of good board dynamics are as follows:

1. The board should meet regularly.

2. The board should maintain a good balance of power.

3. An individual should not be allowed to dominate board meetings and decision making.

4. Members of the board should be open to other members' suggestions.

5. There should be a high level of trust between board members.

6. Board members should be ethical and have a high level of integrity.

7. There must be a high level of effective communication between members of the board.

8. The board should be responsible for the financial statements.

9. Non-executive directors should (generally) provide an independent viewpoint.

10. The board should be open to new ideas and strategies and become a 'learning board'.

11. Board members should not be opposed to change.

12. The board must possess an in-depth understanding of the company's business.

13. The board must be dynamic in nature. 
14. The board must understand the inherent risks of the business.

15. The board must be prepared to take calculated risks; no risk no return.

16. The board must be aware of stakeholder issues and be prepared to engage actively with their stakeholders.

17. As education becomes increasingly important, board members should not be averse to attending training courses.

It is hoped that if corporate Ghana adopts these recommendation sound corporate governance will be the norm rather than the exception. It is also equally expected that wherever these recommendations are also adopted, the expected benefits will be realized.

\section{References}

Adegbite, G. O. (2012). Corporate governance developments in Ghana: the past, the present, and the future. Public and Municipal Finance, 1 (2), 71 - 75.

Agyemang, O. S. \& Castellini, M. (2013). The Guidelines of Corporate Governance of Ghana: Issues, Deficiency and Suggestions. International Business Research, 6 (10), 163 - 173.

Agyemang, O. S., Aboagye, E., \& Ahali, A. Y. O. (2013). Prospects and Challenges of Corporate Governance in Ghana. International Journal of Scientific and Research Publications, 3 (5), 1 - 9.

Benz, M., \& Frey, B. S. (2007). Corporate Governance: What Can We Learn From Public Governance? Academy of Management Review, 32(1), 92-104.

Brick, I. E., Palmon, O., \& Wald, J. K. (2002). CEO Compensation, Director Compensation, and Firm Performance: Evidence of Cronyism. Unpublished Manuscript. Rutgers Business School Newark and New Brunswick.

Dalton, D. R., Daily, C. M., Johnson, J. L., \& Ellstrand, A. E. (1999). Number of Directors and Financial Performance: A Meta-Analysis. Academy of Management Journal, 42(6), 674-686.

Dwivedi, N. \& Jain, A. K. (2005). Corporate Governance and Performance of Indian Firms: The Effect of Board Size and Ownership. Employee Responsibilities and Rights Journal, 17(3), 161172.

Garg, A. J. (2007). Influence of Board Size and Independence on Firm Performance: A Study of Indian Companies. Vikalpa: The Journal for Decision makers, 32(3), 39-60.

Murphy, S. A. \& McIntyre, M. L. (2007). Board of director performance: a group dynamics perspective. Corporate Governance, 7(2), 209-224.

Oppong, S. (2011). Organizational Management: Issues and Trends in Ghana. Saarbrücken, Germany: VDM Publishing House Ltd (ISBN: 978-3-639-35178-1).

Organization for Economic Cooperation and Development. (2012). The DAC List of ODA Recipients. Retrieved Tuesday November 17, 2015 from http://www.oecd.org/dac/stats/49483614.pdf

Securities and Exchange Commission. (2002). Corporate Governance: Guidelines on Best Practices. Accra, Ghana: Securities and Exchange Commission of Republic of Ghana.

Solomon, J., \& Solomon, A. (2010). Corporate Governance and Accountability (African Reprint). New Delhi, India: John Wiley \& Sons/Wiley India Pvt. Ltd.

United Nations. (2007). Development Cooperation with Middle-Income Countries. Retrieved Tuesday November 17, 2015 from http://www.un.org/esa/ffd/events/2007mic/micE.pdf

Vázquez, S. T., \& Sumner, A. (2012). Beyond Low and Middle Income Countries: What if There Were Five Clusters of Developing Countries? Institute of Development Studies Working Paper, 2012 (404), 1 - 40. Retrieved November 17, 2015 from https://www.ids.ac.uk/files/dmfile/Wp404.pdf

World Bank. (2005). Corporate Governance Country Assessment: Ghana. Report on the Observance of Standards and Codes. New York, NY: Author.

World Bank. (2012). How does the World Bank Classify Countries? Retrieved Monday November 16, 2015 from https://datahelpdesk.worldbank.org/knowledgebase/articles/378834-how-does-theworld-bank-classify-countries 